\title{
Institutional Report
}

\section{CSIR-National Institute of Oceanography}

\author{
S W A NAQVI* \\ CSIR-National Institute of Oceanography, Dona Paula, Goa 403 004, India
}

(Received on 11 May 2016; Accepted on 25 June 2016)

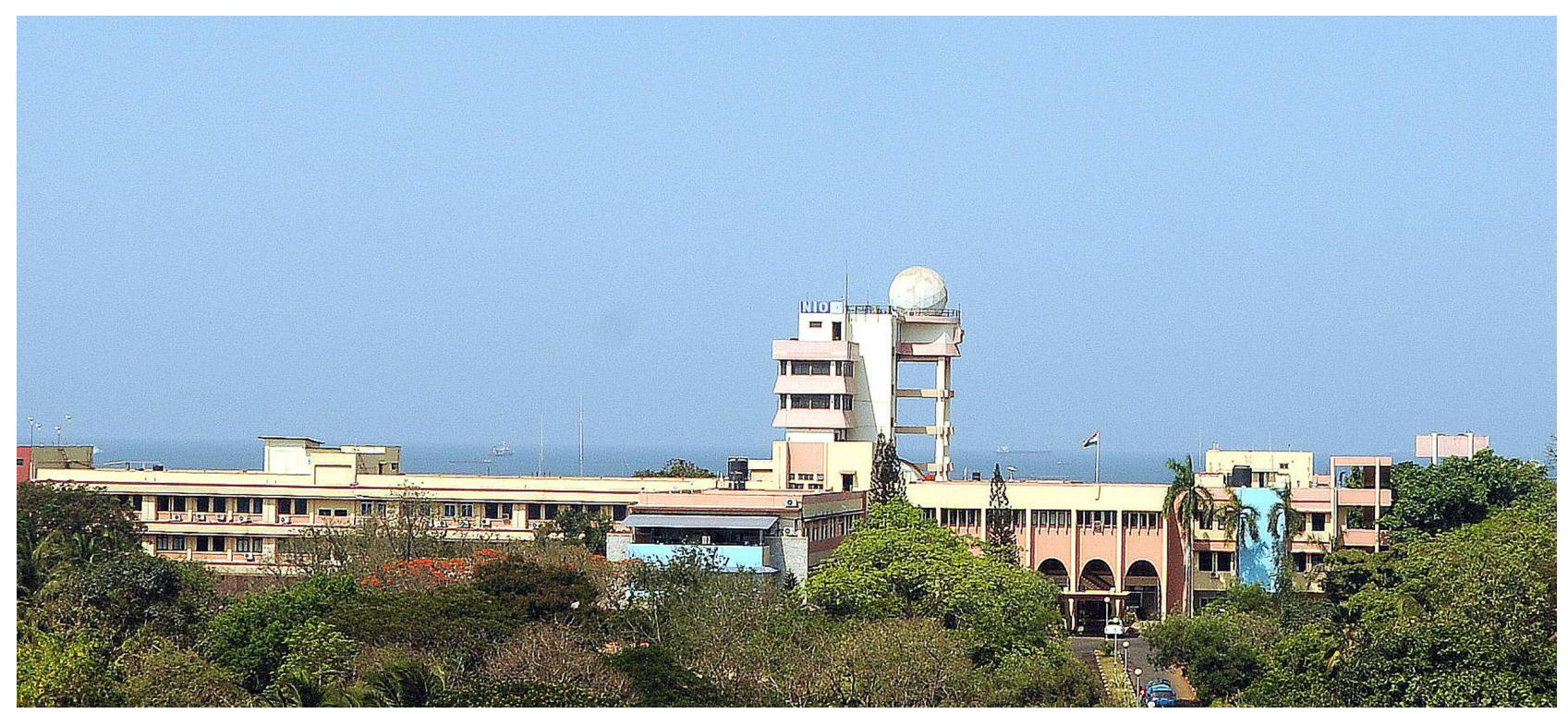

\section{Introduction}

The National Institute of Oceanography (NIO) with its headquarters at Dona Paula, Goa, and regional centres at Kochi, Mumbai and Visakhapatnam, is one of the 37 constituent laboratories of the Council of Scientific \& Industrial Research (CSIR), New Delhi. CSIR-NIO was established on 1 January 1966 as the most important outcome of the International Indian Ocean Expedition (IIOE), the largest international collaborative effort ever undertaken in the oceans. The institute has since grown into a multidisciplinary oceanographic research institution of international repute. The principal focus of research has been on observing and understanding special oceanographic characteristics of the Indian Ocean.
CSIR-NIO has a sanctioned strength of 200 scientists and 100 technical support staff. The major research areas include the four traditional branches of oceanography - biological, chemical, geological/ geophysical, and physical - as well as ocean engineering, marine instrumentation and marine archaeology.

CSIR-NIO has numerous modern laboratories at its headquarters in Goa and its regional centres. It also has a state of the art sea bed sample repository. CSIR-NIO operates two research vessels R V Sindhu Sankalp (56 m) and R V Sindhu Sadhana $(80 \mathrm{~m})$ that are equipped for multidisciplinary oceanographic observations. The institute has a library with 15,000 books and 20,000 back volumes of

\footnotetext{
*Author for Correspondence: E-mail: naqvi@nio.org
} 
research journals, making it the best collection of printed literature on ocean sciences in the country.

In addition to basic research, CSIR-NIO also carries out applied research sponsored by the industry. This includes oceanographic data collection, environmental impact assessment, and modelling to predict environmental impact. The institute also provides consultancy on a number of issues including marine environmental protection and coastal zone regulation.

With the largest collection of ocean scientists in the country, and equipped with suitable ocean research infrastructure, CSIR-NIO serves as an advanced centre of education in ocean sciences. It has a School of Oceanography under the Academy of Scientific \& Innovative Research (AcSIR). In addition, it is a recognized centre for doctoral research by a large number of universities. Presently, there are 430 temporary staffs comprising of project assistants, research fellows and research associates. Of these 41 students are enrolled with the AcSIR. AcSIR has a faculty of 59 scientists who guide these students in their course and research work.

CSIR-NIO has been in the forefront of research in the Indian Ocean since the IIOE. In the early years when it did not have a research vessel of its own, CSIR-NIO's work was largely restricted to coastal areas using small boats besides analysis of samples and processing of data collected during the IIOE. One of the most significant contributions during this period was the publication of atlases documenting distribution of zooplankton in the Indian Ocean by the Indian Ocean Biological Centre (IOBC), Kochi.

In the 1970s, CSIR-NIO researchers began to participate in cruises of the Indian Navy's survey ship Darshak in the Arabian Sea and the Bay of Bengal, which enabled them to make observations beyond coastal waters. The open ocean research was further boosted following the commissioning of CSIR-NIO's first research vessel, Gaveshani, in February 1976. This vessel, a refitted hopper barge, rendered remarkable service to the nation for nearly two decades. With the establishment of the Department of Ocean Development (now the Ministry of Earth Sciences), additional seagoing infrastructure was created by the Government of India through acquisition of O R V Sagar Kanya (in 1983) and F
O R V Sagar Sampada (in 1985); both of these ships were extensively used by CSIR-NIO. Thus, 1980s was a golden decade for oceanography in India when rapid expansion of resources - both manpower and infrastructure - occurred not only in NIO but in the country as a whole.

Availability of research vessels enabled India not only to participate actively in all major international programmes in the Indian Ocean such as the Monsoon Experiment (MONEX), Joint Global Ocean Flux Study (JGOFS) and Climate and Ocean: Variability, Predictability and Change (CLIVAR), but also to conduct research under various in-house and national programmes. A number of important bilateral projects were also undertaken especially in collaboration with researchers from France, Germany and USA.

Perhaps the most important contributions made by CSIR-NIO since its foundation relate to processes unique to the North Indian Ocean region arising from its unusual geography. The most striking of these is the seasonal reversal of surface currents. Although this reversal had been generally known for a long time, detailed description based on systematic observations and theoretical framework, needed to understand the forcing mechanisms, was lacking. CSIR-NIO's research immensely contributed to the present knowledge of physical processes in the Indian Ocean. It is now recognized that due to the tropical nature and small basin size circulation in the entire North Indian Ocean including the equatorial region is linked on basin scale, and it is both locally and remotely forced. Long term deployments of current meter moorings along the east and west coasts of India as well as in the Equatorial Indian Ocean region, as a part of a globally coordinated effort, have led to recognition of variability of currents and provided insights into causative processes on a variety of time scales (intraseasonal, seasonal and interannual) that also affect biogeochemistry and ecology.

The earliest recognition of special features of biogeochemistry of the North Indian Ocean goes back to the John Murray Expedition (1933-34) during which the intense oxygen minimum zone of the Arabian Sea was first noticed. Surveys during the IIOE led to mapping of physico-chemical variables, phyto- and zooplankton and primary production. However, focused process studies were initiated only after the 
IIOE, and CSIR-NIO played a leading role in these studies. It spearheaded the Indian JGOFS' Arabian Sea Process Study. Subsequently a similar project the Bay of Bengal Process Study (BoBPS) - was implemented as a national programme in the Bay of Bengal. It was followed by Sustained Indian Ocean Biogeochemical and Ecological Research (SIBER). CSIR-NIO also played a leading role in implementation of LOICZ (Land-Ocean Interaction in the Coastal Zone) and SOLAS (Surface Ocean - Lower Atmosphere Study), two other international projects of SCOR/IGBP. In addition, it participated in two very productive bilateral programmes on biogeochemistry, one with the University of Hamburg (Germany) and the other with IRD (Institut de Researche pour le Developpement), Paris, France. Sustained efforts, including establishment of time series sites, provided important insights into physical-biogeochemical coupling and how it is related to the monsoons and biogeochemistry-microbial ecology of the OMZ. Some of the most exciting results came from a sediment trap time series study carried out under an IndoGerman collaborative project. Similarly, systematic, long term observations on biogeochemistry and microbiology of the open ocean $\mathrm{OMZ}$ and in the world's largest coastal low oxygen zone that develops seasonally over the western Indian continental shelf led to important advancement of our understanding of oceanic OMZs. The key role of microbial loop in carbon cycling arising from winter convection was highlighted by research carried out by the Institute as was the previously unrecognized limitation of iron limitation of primary production in the Arabian Sea. Also, striking biogeochemical contrasts between the eastern and western Arabian Sea and between the Arabian Sea and the Bay of Bengal were brought to the fore as a result of CSIR-NIO's research efforts. It may be pointed out that while the Arabian Sea has been the focus of numerous international programmes the bulk of research in the Bay of Bengal has been carried out by CSIR-NIO, the results of which are attracting increasingly larger number of oceanographers from other parts of the world to this region.

CSIR-NIO is the leading institution in the Indian Ocean investigating impacts of human activities on ocean physics, biogeochemistry and ecosystems. This includes investigations on sealevel rise and effects of ongoing global changes such as ocean warming, eutrophication, deoxygenation and acidification. CSIRNIO has been spearheading for nearly four decades a national programme - Coastal Ocean Monitoring and Prediction System (COMAPS) - to continuously evaluate the state of pollution along the Indian coast. It is also the nodal agency for the national programme on ballast water management.

Reconstruction of past changes utilizing sedimentary record has been one of the major activities at CSIR-NIO, and this research, linked to the international Past Global Changes (PAGES) programme, has led to marked improvement of understanding of changes in circulation, biology and chemistry of the North Indian Ocean including the equatorial region, and also of regional climate that is dominated by the monsoons. Monsoon variability and associated oceanographic changes in the geological past have been documented on a variety of time scales. Development of new proxies and capabilities such as foraminifera culture contributed immensely to the success of these programmes.

In geological oceanography, the single largest discipline in NIO, a great deal of work has also been carried out to identify and evaluate non living resources of the Indian Ocean. These include placer deposits in coastal waters, polymetallic nodules (PMN) in the Central Indian Ocean, and gas hydrates in the Indian EEZ. The PMN programme was the flagship project of CSIR-NIO in the 1980s and 1990s. It not only led to India's recognition as a Pioneer Investor by the International Seabed Authority and the allocation of a mining site measuring $75,000 \mathrm{~km}^{2}$ in the Central Indian Ocean, but it also facilitated extensive research on sedimentary geochemistry, paleoclimare/paleoceanography, and geophysics.

In geophysics, another thrust area, CSIR-NIO's research efforts covered both continental margins and deep-sea regions. Geophysical surveys in the Central Indian Ocean deciphered response of oceanic lithosphere to the collision of India with Eurasia at different time periods. Observations in the Arabian Sea led to delineation of ocean-continent boundary and development of advanced plate tectonic models for this part of Indian Ocean. New hydrothermal vent sites were identified over the Carlsberg Ridge. Investigations in the Bay of Bengal facilitated an understanding of the nature of crust beneath the thick sediment cover. Identification of mesozoic magnetic 
anomalies in this region and deciphering evolution of the $85^{\circ} \mathrm{E}$ Ridge were other important contributions. Research on the Ninetyeast Ridge revealed Kerguelen hotspot - spreading ridge interactions and differential plate motions in the Indian Ocean. Recent seismic stratigraphic records from this region revealed an abrupt increase in sediment inputs by the Ganges and Brahmaputra rivers around 23 million years ago. The results also led to a tectonic model for the evolution of the Andaman back arc basin. Studies in KrishnaGodavari Basin provided insights into processes leading to gas hydrate formation.

CSIR-NIO took active part in important national programmes such as geophysical surveys for delineating the Legal Continental Shelf, and geoscientific studies of the Exclusive Economic Zone of India.

CSIR-NIO has built a number of instruments for automated observations, most notable among them are automated weather stations, tide gauges, an autonomous underwater vehicle and an autonomous vertical profiler.

The multidisciplinary expertise developed within

\section{Publications}

Bhattathiri P M A, Pant A, Sawant S S, Gauns M, Matondkar S G P and Mohanraju R (1996) Phytoplankton production and chlorophyll distribution in the eastern and central Arabian Sea in 1994-1995 Curr Sci 71 857-862

Gomes H R, Goes J I and Saino T (2000) Influence of physical processes and freshwater discharge on the seasonality of phytoplankton regime in the Bay of Bengal Cont Shelf Res 20 313-330

Hashimi N H, Nigam R, Nair R R and Rajagopalan G (1995) Holocene sea level fluctuations on western Indian continental margin: An update J Geol Soc India 46 157162

Ittekkot V, Nair R, Honjo S, Ramaswamy V, Bartsch M, Manganini S J and Desai B N (1991) Enhanced particle fluxes in Bay of Bengal induced by injection of freshwater Nature 351 385-387

Kamesh Raju K A, Ramprasad T, Rao P S, Rao B R and Varghese J (2004) New insights into the tectonic evolution of the Andaman basin, northeast Indian Ocean Earth Planet Sci Lett 221 145-162 the Institute enabled CSIR-NIO to help numerous industries in coastal area. It has been offering services to both private and public sector organizations on various issues related to coastal zone utilization/ management. It has carried out over 1300 projects sponsored by outside agencies generating external cash flow which accounts for over a quarter of its annual budget.

CSIR-NIO is the primary centre in the country for human resource development in marine sciences. It has trained over 2000 graduate and post graduate students for their dissertations. Moreover, over 300 students have earned Ph.D. degrees working at the Institute. CSIR-NIO also organizes several training programmes for students, researchers, policy makers and other stakeholders that are open for participants from the Indian Ocean Rim Countries and SAARC (South Asia Association for Regional Cooperation) nations on management and sustainable utilization of marine resources.

The immense scientific contribution made by CSIR-NIO is evident from its impressive scientific output - around 3,800 research papers, 41 of which have been cited more than 100 times each.

Kumar M D, Naqvi S W A, George M D and Jayakumar D A (1996) A sink for atmospheric carbon dioxide in the northern Bay of Bengal J Geophys Res 101 121-125

Madhupratap M, Prasanna Kumar S, Bhattathiri P M A, Dileep Kumar M, Raghukumar S, Nair K K C and Ramaiah N (1996) Mechanism of the biological response to winter cooling in the northeastern Arabian Sea Nature 8 549-552

Madhupratap M, Gauns M, Ramaiah N, Prasanna Kumar S, Muraleedharan P M, DeSousa, S N, Sardessai S and Muraleedharan U D (2003) Biogeochemistry of the Bay of Bengal: physical, chemical and primary productivity characteristics of the central and western Bay of Bengal during summer monsoon 2001 Deep-Sea Res II 50 881896

Nair R R, Ittekkot V, Manganini S J, Ramaswamy V, Haake B, Degens E T, Desai B N and Honjo S (1989) Increased particle flux to the deep ocean related to monsoons Nature 338 749-751

Naqvi S W A (1987) Some aspects of the oxygen deficient conditions and denitrification in the Arabian Sea J Mar Res 4910491072 
Naqvi W A (1991) Geographical extent of denitrification in the Arabian Sea in relation to some physical processes Oceanolog Acta 14281290

Naqvi S W A and Noronha R J (1991) Nitrous oxide in the Arabian Sea Deep Sea Res 38871890

Naqvi S W A, Yoshinari T, Jayakumar D A, Altabet MA, Narvekar P V, Devol A H, Brandes J A and Codispoti L A (1998) Budgetary and biogeochemical implications of $\mathrm{N}_{2} \mathrm{O}$ isotope signatures in the Arabian Sea Nature 394 462-464

Naqvi S W A, Jayakumar D A, Narvekar P V, Naik H, Sarma V V S S, D'Souza W, Joseph T and George M D (2000) Increased marine production of $\mathrm{N}_{2} \mathrm{O}$ due to intensifying anoxia on the Indian continental shelf Nature 408 346-349

Naqvi S W A, Moffett J W, Gauns M, Narvekar P V, Pratihary A K, Naik H, Shenoy D M, Jayakumar D A, Goepfert T J, Patra P K, Al-Azri A and Ahmed S I (2010) The Arabian Sea as a high-nutrient, low-chlorophyll region during the late southwest monsoon Biogeosciences 7 2091-2100

Prasanna Kumar S, Muraleedharan P M, Prasad T G, Gauns M, Ramaiah N, DeSousa S N, Sardessai S and Madhupratap M (2002) Why is the Bay of Bengal less productive during summer monsoon compared to the Arabian Sea Geophys Res Lett 29 doi:10.1029/2002GL016013

Qasim S Z (1982) Oceanography of the northern Arabian Sea Deep-Sea Res 29 1041-1068

Qasim S Z and Sen Gupta R (1981) Environmental characteristics of the Mandovi-Zuari estuarine system in Goa Estuar Coast Mar Sci 13 557-578

Raghukumar S (2002) Ecology of the marine protists, the Labyrinthulomycetes (Thraustochytrids and Labyrinthulids) Eur J Protistol 38 127-145

Ramana M V, Nair R R, Sarma K V L N S, Ramprasad T, Krishna K S, Subrahmanyam V, D'Cruz M, Subrahmanyam C, Paul J, Subrahmanyam A S and Sekhar D V C (1994) Mesozoic anomalies in the Bay of Bengal Earth Planet Sci Lett 21 469-475

Rao D G, Krishna K S and Sar D (1997) Crustal evolution and sedimentation history of the Bay of Bengal since the Cretaceous J Geophys Res 102 747-768

Ray D, Kamesh Raju K A, Baker E T, Rao A S, Mudholkar A V, Lupton J E, Surya Prakash, L, Gawas R B and Vijaya Kumar T (2012) Hydrothermal plumes over the Carlsberg Ridge, Indian Ocean Geochem Geophys Geosyst 13 doi: 10.1029/2011GC003888

Sarkar A, Ray D, Shrivastava A N and Sarkar S (2006) Molecular biomarkers: Their significance and application in marine pollution monitoring Ecotoxicology 15 333-340
Sathyendranath S, Gouveia A D, Shetye S R, Ravindran P and Platt T (1991) Biological control of surface temperature in the Arabian Sea Nature 349 54-56

Sen Gupta R and Naqvi S W A (1984) Chemical oceanography of the Indian Ocean, north of the equator Deep-Sea Res 31 671-706

Shankar D and Shetye S R (1997) On the dynamics of the Lakshadweep high and low in the southeastern Arabian Sea J Geophys Res 102 551-562

Shankar D, Vinayachandran P N and Unnikrishnan A S (2002) The monsoon currents in the north Indian Ocean Prog Oceanogr 52 63-120

Shenoi S S C, Shankar D and Shetye S R (2002) Differences in heat budgets of the near-surface Arabian Sea and Bay of Bengal: Implications for the summer monsoon J Geophys Res 107 doi: 10.1029/2000JC000679

Shetye S R, Gouveia A D, Shenoi S S C, Sundar D, Michael G S, Almeida A M and Santanam K (1990) Hydrography and circulation off the west coast of India during the southwest monsoon 1987 J Mar Res 48 359-378

Shetye S R, Gouveia A D, Shenoi S S C, Michael G S, Sundar D, Almeida A M and Santanam K (1991) The coastal current off western India during the northeast monsoon Deep-Sea Res 38 1517-1529

Shetye S R, Shenoi S S C, Gouveia A D, Michael G S, Sundar D and Nampoothiri G (1991) Wind-driven coastal upwelling along the western boundary of the Bay of Bengal during the southwest monsoon Cont Shelf Res 11 1397-1408

Shetye S R, Gouveia A D, Shenoi S S C, Sundar D, Michael G S and Nampoothiri G (1993) The western boundary current of the seasonal subtropical gyre in the Bay of Bengal $J$ Geophys Res 98 945-954

Shetye S R, Gouveia AD, Shankar D, Shenoi S S C, Vinayachandran P N, Sundar D, Michael G S and Nampoothiri G (1996) Hydrography and circulation in the western Bay of Bengal during the northeast monsoon J Geophys Res 101 1401114025

Varkey M J, Murty V S N and Suryanarayana A (1996) Physical oceanography of the Bay of Bengal and Andaman Sea Oceanogr Mar Biol Annu Rev 34 1-70

Wafar S, Untawale A G and Wafar M V M (1997) Litter fall and energy flux in a mangrove ecosystem Estuar Coast Shelf Sci 44111-124. 